Original Article

\title{
Antimicrobial, antioxidant activity and phytochemical prospection of Eugenia involucrata DC. leaf extracts
}

\author{
Atividade antimicrobiana, antioxidante e prospecção fitoquímica dos extratos \\ das folhas de Eugenia involucrata DC.
}

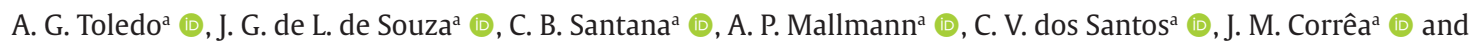 \\ F. G. da S. Pinto ${ }^{\mathrm{a}^{*}}$ (D) \\ aUniversidade Estadual do Oeste do Paraná - UNIOESTE, Programa de Conservação e Manejo de Recursos Naturais, Laboratório de \\ Microbiologia e Biotecnologia - LAMIBI, Cascavel, PR, Brasil
}

\begin{abstract}
The species Eugenia involucrata DC. is a plant native to Brazil and is traditionally used for intestinal problems, however, little research has documented about its biological potential and phytochemical profile. Thus, the objective of this study was to carry out preliminary phytochemical prospecting, antimicrobial and antioxidant potential of E. involucrata extracts. Using the E. involucrata leaves, aqueous and organic extracts were obtained using the following solvents (ethanol, methanol, hexane, acetone, dichloromethane and ethyl acetate). The phytochemical prospecting detected the presence of saponins, steroids, flavonoids and tannins in the extracts. Ethanolic and methanolic extracts presented antimicrobial activity for most of the bacterial strains tested, as well as for yeast Candida albicans, with concentrations between 3.12 and $50 \mathrm{mg} / \mathrm{mL}$. The ethanolic and metanolic extract presented high free radical sequestration potential $(>90 \%)$. The methanol extract showed an $\mathrm{IC}_{50}$ value statistically equal to that found for the commercial antioxidant BHT $(\mathrm{p}<0.05)$. The crude extracts obtained with ethanol and methanol were the most promising. These results suggest that methanolic, ethanolic and aqueous extracts are a promising source of natural bioactive.
\end{abstract}

Keywords: Eugenia involucrata, Myrtaceae, free radicals, antimicrobial activity.

\begin{abstract}
Resumo
A espécie Eugenia involucrata DC. é uma planta nativa do Brasil e tradicionalmente utilizada para problemas intestinais, porém, poucas pesquisas documentam sobre seu potencial biológico e perfil fitoquímico. Assim, o objetivo deste trabalho foi realizar uma prospecção fitoquímica preliminar, o potencial antimicrobiano e antioxidante dos extratos de E. involucrata. A partir das folhas de E. involucrata, foram obtidos extratos aquosos e orgânicos com os seguintes solventes (etanol, metanol, hexano, acetona, diclorometano e acetato de etila). A prospecção fitoquímica detectou a presença de saponinas, esteroides, flavonóides e taninos nos extratos. Os extratos etanólico e metanólico apresentaram atividade antimicrobiana para a maioria das cepas bacterianas testadas, assim como para a levedura Candida albicans, com concentrações entre 3,12 e $50 \mathrm{mg} / \mathrm{mL}$. Os extratos etanólico e metanólico apresentaram alto potencial de sequestro de radicais livres (>90\%). 0 extrato metanólico apresentou $\mathrm{IC}_{50}$ estatisticamente igual ao encontrado para o antioxidante comercial BHT ( $\left.\mathrm{p}<0,05\right)$. Os extratos brutos obtidos com etanol e metanol foram os mais promissores. Esses resultados sugerem que os extratos metanólico, etanólico e aquoso são uma fonte promissora de bioativos naturais.
\end{abstract}

Palavras-chave: Eugenia involucrata, Myrtaceae, radicais livres, atividades antimicrobiana.

\section{Introdution}

In developing countries, medicinal plants are often the only treatment available to the population, and their use has been increasingly recognized in traditional medicine (WHO, 1998; Teixeira and Silva, 2013). Plant species provide a wide variety of pharmacologically active constituents. Moreover, because of their practicality in preparations of infusions teas, this has allowed for their prolonged use in folk medicine (Ziani et al., 2015).

In recent years, there has been a growing interest in native plants due to of their health benefits. Brazil, as one of the places with the highest abundance of plant biodiversity, has become a country of great origin in the search for biologically active principles, supplying raw materials

*e-mail: fabiana.pinto@unioeste.br

Received: November 19, 2020 - Accepted: February 25, 2021 
to obtain high value chemical products (Andrade et al., 2009; Oliveira et al., 2012; Lazzarotto-Figueiró et al., 2021).

In the investigation of native medicinal plants, the family Myrtaceae includes one of its largest representatives, the genus Eugenia, which comprises about 400 species distributed throughout Brazil (Sobral et al., 2015). This genus is quite interesting from a chemical and pharmacological point of view and stands out for its therapeutic potential. Studies with species of this genus have shown promising results, such as antioxidant (Moresco et al., 2016) anti-inflammatory (Infante et al., 2016), antiviral (Sood et al., 2012), antibacterial (Simonetti at al., 2016; Lazzarotto-Figueiró et al., 2021) and hypoglycemic (Sharma et al., 2008).

The species Eugenia involucrata DC. is a native arboreal plant. It is specific to the Mata Atlântica region, popularly known in Brazil as “cerejeira-do-mato”, “cerejeira-da-terra”, "cereja-do-rio-grande" or "cereja-preta". This species is widely used in the economic sector due to the presence of edible fruits and in the recovery of degraded areas (Lorenzi, 2009). In folk medicine, its leaves are used as an infusion for the treatment of diarrhea and poor digestion (Sausen et al., 2009; Hüller and Schock, 2011).

Little is known about the antimicrobial and antioxidant properties of E. involucrata leaves, which is intriguing considering the biological potential of the genus. In the literature, no studies have reported the antimicrobial activity of this species, and only recently, the antioxidant activity of leaf essential oil (Ciarlini et al., 2017) and E. involucrata fruit has been reported (Marin et al., 2008; Infante et al., 2016; Nicácio et al., 2017). In this sense, studies related to the chemical composition and biological potential of plant species become increasingly relevant, allowing for the validation of ethnobotanical knowledge and the appreciation of native flora.

Therefore, the present study aimed to perform a preliminary phytochemical prospection of the main groups of secondary metabolites present in the plant extracts of $E$. involucrata leaves, as well as to investigate the antimicrobial and antioxidant potential of this species.

\section{Material and Methods}

\subsection{Collection and identification of plant material}

The collection of E. involucrata leaves were carried out in the ecological park Paulo Gorski ( $24^{\circ} 57$ ' $49.8^{\circ}$ "S $53^{\circ}$ $\left.26^{\prime} 1.4^{\prime \prime} \mathrm{W}\right)$, located in the municipality of Cascavel-PR, between the months of October 2016 and March 2017. The plant was identified by the botanist Livia Godinho Temponi, an exsiccate was deposited in the State University of the West of Paraná Herbarium (UNOP) under voucher number UNOP 1883.

\subsection{Obtaining plant extracts}

The extracts were prepared according to the methodology proposed by (Pandini et al., 2015), with modifications. The dry vegetable material (10 g) was extracted with different solvents $(100 \mathrm{~mL})$ : methanol $(\mathrm{MeOH})$, ethanol (EtOH), ethyl acetate (EtAce), acetone (Ace), hexane (Hex), dichloromethane (DCM) and distilled water (DW). These liquid preparations were maintained on a rotary shaker at $220 \mathrm{x}$ g for $24 \mathrm{~h}$. They were filtered using Whatman $\mathrm{n}^{\mathrm{0}} 1$ filter paper and centrifuged at $5000 \mathrm{x} g$ for $15 \mathrm{~min}$. The supernatant was collected and the solvent was removed on a rotary evaporator, except for the aqueous extract, which was lyophilized. At the end of the experiment, the crude and organic extracts were collected and stored under refrigeration at $4{ }^{\circ} \mathrm{C}$. The yield of the extracts (\%) was calculated by Equation 1 .

$$
\% E=\left[g \frac{\text { extract }}{\text { dry and ground vegetable }}\right] \times 100
$$

\subsection{Phytochemical prospecting}

Tests concerning the phytochemical prospection of the different E. involucrata plant extracts were carried out according to the methodology described by (Matos, 1997). These tests were based on colorimetric visualization and/or precipitate formation after the addition of specific reagents to identify the following classes of secondary metabolites: saponins, free steroids, triterpenoids, alkaloids, anthocyanins, anthocyanidins, aurones, chalcones, flavanones, flavones, flavonols, xanthones, condensed tannins and coumarins. The qualitative results were expressed as presence/positive reaction (+), weakly positive or strong positive reaction (++) with higher intensity (more concentrated reactions), and absence/negative reaction (-) of phytochemicals.

\subsection{Antimicrobial activity}

\subsubsection{Microorganisms used}

The plant extracts were tested against the strains of the American Type Culture Collection (ATCC) and the Collection of Cultures Cefar Diagnostic (CCCD). As Gram negative representatives, the strains Escherichia coli (ATCC 25922), Salmonella enterica Enteritidis (ATCC 13076), Salmonella enterica Typhimurium (ATCC 14028), Pseudomonas aeruginosa (ATCC 27853), Proteus mirabilis (ATCC 25933) and Klebsiella pneumoniae (ATCC 13883) were used; as Gram positive representatives, Staphylococcus aureus (ATCC 25923), Enterococcus faecalis (ATCC 19433), Staphylococcus epidermidis (ATCC 12228) and Bacillus subtilis subsp. spizizenii (CCCD B005) were used. As a fungus representative, the yeast Candida albicans (ATCC 10231) was used.

The microorganisms were recovered in Brain Heart Infusion broth and incubated for $24 \mathrm{~h}$ at $36 \pm 0.1^{\circ} \mathrm{C}$. After this period, the strains were streaked on Mueller Hinton agar $(\mathrm{MH})$ and incubated for $24 \mathrm{~h}$ at $36 \pm 0.1^{\circ} \mathrm{C}$. To standardize the inoculum, the strains were diluted in saline solution $(0.85 \%)$ resulting in a final concentration of $1 \times 10^{5} \mathrm{UFC} / \mathrm{mL}$ for bacteria and $1 \times 10^{6} \mathrm{UFC} / \mathrm{mL}$ for $C$. albicans yeast. The inoculum was compared by turbidity with the reading standard 0.5 on the McFarland scale and the absorbance of the suspension read in a spectrophotometer $(A 600=0.3)$.

\subsubsection{Minimum inhibitory concentration (MIC)}

The assays were performed according to the broth microdilution methodology described by (Weber et al., 2014), with modifications. The E. involucrata plant extracts 
crude were solubilized in methanol, obtaining a stock solution (400 mg/mL). For the assay with the bacterial strains, a serial dilution of the stock solution of crude extract in $\mathrm{MH}(1: 1)$ was performed. Roswell Park Memorial Institute (RPMI) broth (1:1) was used for C. albicans yeast. Concentrations of the extract were obtained between 200 to $0.09 \mathrm{mg} / \mathrm{mL}$. At the end, the inoculum $(10 \mu \mathrm{L})$ was added and the plates were incubated at $36 \pm 0.1^{\circ} \mathrm{C}$ for $18-24 \mathrm{~h}$. For the positive control, the commercial antibiotic gentamycin $(200 \mathrm{mg} / \mathrm{mL})$ and the commercial anti-fungal nystatin $(200 \mathrm{mg} / \mathrm{mL})$ were used. As a negative control, the inoculum was added to the MH/RPMI broth, without the presence of the extract, to verify the viability of the tested microorganism. The sterility control of the solubilized extracts in methanol P.A. and a control of the diluent methanol P.A. were also performed to check for interference in the assay. Triphenyltetrazolium chloride (10 $\mu \mathrm{L} \mathrm{TTC}, 0.5 \%)\left(36 \pm 0.1^{\circ} \mathrm{C}\right.$ for $15 \mathrm{~min}$.) was used as a colorimetric developer. MIC was performed in triplicate, and it was possible to determine the lowest concentration of extracts capable of inhibiting microbial growth.

\subsubsection{Minimum bactericidal concentration (MBC) and minimum fungicidal concentration (MFC)}

For this test, the methodology of (Weber et al., 2014) was used, with modifications. Before the addition of $0.5 \%$ TTC to determine the MIC, an aliquot of $2 \mu \mathrm{L}$ was removed from each dilution present in the microdilution plate wells, being sown on the surface of the $\mathrm{MH}$ agar. The plates were incubated at $36 \pm 0.1{ }^{\circ} \mathrm{C}$ for $18-24 \mathrm{~h}$. The assay was carried out in triplicate to determine CBM/CFM, which was observed if there was microbial growth in the $\mathrm{MH}$ agar, allowing for the verification of the lowest concentration of the plant extracts capable of causing the death of the tested bacterium/yeast.

\subsection{Antioxidant activity}

The antioxidant activity of the vegetable extracts was carried out according to the method for the reduction of the free radical 2,2-diphenyl-1-picryl-hydrazil (DPPH), proposed by (Rufino et al., 2007), with modifications. First, a calibration curve $(0,10,20,30,40,50$ and $60 \mu \mathrm{M}$ $\mathrm{DPPH}$ ) was made to obtain the DPPH concentration in the medium after reaction with the extract, resulting the Equation $2\left(R^{2}=0.999\right)$, where $y$ is the concentration of $\mathrm{DPPH}$ and $\mathrm{x}$ is the absorbance. Then, the plant extracts were solubilized in methanol P.A. (concentrations of 0.1 to $15 \mathrm{mg} / \mathrm{mL}$ ). An aliquot of $0.1 \mathrm{~mL}$ of extract was added to $3.9 \mathrm{~mL}$ of a methanolic solution of DPPH $(60 \mu \mathrm{M})$. Then the absorbance reading was performed in a spectrophotometer (FEMTO, 700 Plus) at $515 \mathrm{~nm}$. The synthetic antioxidant BHT (butyl hydroxy toluene) was used as a positive control (concentrations of 0.025 to $0.5 \mathrm{mg} / \mathrm{mL}$ ). All concentrations were defined from a preliminary test to determine the antioxidant activity in the approximate range of 20 to $80 \%$ free radical sequestration DPPH. The percentage of free radical sequestration $(A A \%)$ was expressed by the Equation 3 , where $A_{0}$ is the absorbance of the negative control and $A_{1}$ is the absorbance of the sample. For the calculation of $\mathrm{IC}_{50}$ (amount of antioxidant substance required to reduce the initial concentration of DPPH by $50 \%$ ), the concentrations of the plant extracts and BHT were used to obtain the equation of the line with a $\mathrm{R}^{2}$ greater than 0.80 , from the linear regression. The tests were performed in triplicate and expressed as mean \pm standard deviation. The $\mathrm{IC}_{50}$ results were analyzed using an ANOVA with Tukey's test ( $\mathrm{p}<0.05$ ) using the statistical software $\mathrm{R}^{\circledR}$ version 3.3.2.

$$
\begin{aligned}
& y=0.0117 x+0.0102 \\
& A A \%=\left[\frac{A_{0}-A_{1}}{A_{0}}\right] x 100
\end{aligned}
$$

\section{Results and Discussion}

\subsection{Phytochemical prospecting}

The following yields were obtained from the preparation of E. involucrata plant extracts with different solvents: $\mathrm{MeOH}$ (23.6\%), EtOH (19.42\%), Ace (9.38\%), EtAce (6\%), Hex (6.35\%), DCM (6.31\%) and DW (9.84\%).

Phytochemicals are extracted from the plant's secondary metabolism. The synthesis of these metabolites is directly influenced by external factors such as soil conditions, temperature and water availability. Therefore, the environmental conditions in which the plant is found will determine the bioactive potential and the phytochemical profile that will be found in the extract (Lin et al., 2020).

The process of extracting phytochemical compounds from plants is a physical-chemical operation of mass transfer, in which soluble and volatile solids can be extracted (Poirot et al., 2006). The yield of crude plant extracts is influenced by the conditions under which the extraction process is carried out (temperature, extraction time, solid-solvent ratio, particle agitation and pressure, polarity and solubility). In addition, the plant matrix has a complex cellular microstructure that meets the unique molecular structure of the solute, ensuring that each extraction system shows skin behavior, which cannot be easily predicted (Cabana et al., 2013; Fernández-Agulló et al., 2013; Pinelo et al., 2004; Wongkittipong et al., 2004).

The phytochemical investigation of extracts revealed the presence of compounds belonging to the classes of saponins, free steroids, flavonoids (flavones, flavanols, and flavanonols), xanthones and tannins (Table 1). Free steroids were the only class of secondary metabolites that were present in all extracts. The extracts that presented the greatest diversity of secondary metabolites were EtOH and DW, followed by the extracts of $\mathrm{MeOH}$, EtAce, Ace, Hex, and DCM. The literature reports that plant extracts commonly rich in metabolites use extraction solvents these are mainly methanol, ethanol and acetone (Cabana et al., 2013; Fernández-Agulló et al., 2013).

Despite the majority of popular medicinal preparations used, it will be water-based that was removed from organic solvents plants provide more consistent antimicrobial activity. A majority of two polyphenolic bioactive composts, such as flavonoids, are generally solubilized in polar solvents, such as ethanol and methanol. A most useful theory for the low activity of the aqueous extract 
Table 1. Phytochemical prospection of aqueous and organic solvent extracts from leaves of E. involucrata.

\begin{tabular}{|c|c|c|c|c|c|c|c|}
\hline \multirow{2}{*}{$\begin{array}{l}\text { Chemical } \\
\text { compounds }\end{array}$} & \multicolumn{7}{|c|}{ Extracting solvente } \\
\hline & МeOH & EtOH & EtAce & Ace & Hex & DCM & DW \\
\hline Saponins & ++ & + & - & - & - & - & ++ \\
\hline Free steroids & + & + & + & + & + & + & + \\
\hline Triterpenoids & - & - & - & - & - & - & - \\
\hline Alkaloids & - & - & - & - & - & - & - \\
\hline Anthocyanins & - & - & - & - & - & - & - \\
\hline Anthocyanidins & - & - & - & - & - & - & - \\
\hline Flavones & - & + & + & - & - & - & + \\
\hline Flavanols & - & + & + & - & - & - & + \\
\hline Xanthones & - & + & + & - & - & - & + \\
\hline Chalcones & - & - & - & - & - & - & - \\
\hline Aurones & - & - & - & - & - & - & - \\
\hline Flavanones & + & - & - & - & - & - & - \\
\hline Condensed tannins & ++ & ++ & - & + & - & - & + \\
\hline Coumarins & - & - & - & - & - & - & - \\
\hline
\end{tabular}

Methanol (MeOH), ethanol (EtOH), ethyl acetate (EtAce), acetone (Ace), hexane (Hex), dichloromethane (DCM) and distilled water (DW); (+) Positive reaction, (++) strong positive reaction and (-) negative reaction.

can be attributed to the polyphenol oxidase enzyme, which degrades polyphenols in aqueous extracts, while in methanol and ethanol are not active. Furthermore, water is a suitable medium for the proliferation of microorganisms when compared to alcohol. Or ethanol, due to its physico-chemical characteristics, it is easier to penetrate the cell membrane to extract intracellular compost from plant material that is active against microorganisms (saturated or aromatic organic compost) (Tiwari et al., 2011).

The difference in the composition of the extracts can be explained by the richness of the metabolites that were present, the yield during the extraction, as well as the polarity characteristics of the solvent used, with these being the determinants in the extraction of bioactive compounds with biological potential (Fernández-Agulló et al., 2013; Pimentel et al., 2013).

Within the genus Eugenia, the most common classes of secondary metabolites are flavonoids, triterpenoids and tannins (Queiroz et al., 2015). However, there have been no studies that have related to the presence of phytochemicals in the leaf extracts of E. involucrata. However, the fruit has been well studied, proving the presence of phenolic compounds, and as in our research, confirming the potential of the species as a raw material for the extraction of bioactive compounds (Infante et al., 2016; Nicácio et al., 2017).

\subsection{Antimicrobial activity}

In the broth microdilution assay, all plant extracts from E. involucrata leaves were tested for their ability to inhibit growth (MIC) or cause death (MBC/MFC) of microorganisms (Table 2). The MIC and MBC/MFC of the plant extracts were classified according to Pandini et al. (2015) as: high ( $<12.5 \mathrm{mg} / \mathrm{mL}$ ), moderate (12.5 to $25 \mathrm{mg} / \mathrm{mL}$ ), low (50 to $100 \mathrm{mg} / \mathrm{mL}$ ) and very low (> $100 \mathrm{mg} / \mathrm{mL}$ ).

Extract activity varied according to the extracting solvent and the tested microorganism. Thus, all of the E. involucrata extracts presented antimicrobial potential fronts for the 11 tested strains, except for DW, which did not present antimicrobial activity against the K. pneumoniae strain. This extract presented the lowest activities, with MIC and MBC values between 50 and $200 \mathrm{mg} / \mathrm{mL}$; however, it revealed a greater presence of groups of secondary compounds. As it is a qualitative method, phytochemical prospecting does not allow for the quantification of these groups, and the presence of these groups in low quantities was probably not sufficient to promote the effective inhibition of the tested pathogens.

The antimicrobial activity of the extracts declined in the following order: $\mathrm{MeOH}>\mathrm{EtOH}>$ Ace $>$ EtAce $>\mathrm{DCM}>\mathrm{Hex}>\mathrm{DW}$. $\mathrm{MeOH}$ and $\mathrm{EtOH}$ presented the greatest activities, compared to the other extracts. $\mathrm{MeOH}$ presented antimicrobial activity values ranging from 3.12 to $25 \mathrm{mg} / \mathrm{mL}$, which is classified as between high and moderate activity; EtOH showed antimicrobial activity values between 3.12 and $50 \mathrm{mg} / \mathrm{mL}$, presenting variation between high, moderate and low activity. These extracts showed very similar antimicrobial properties and similar phytochemical compounds, only presenting differences in the types of phenolic compounds found. $\mathrm{MeOH}$ presented flavanonols, whereas EtOH showed the presence of flavones, flavanols and xanthones, which may justify the variation in antimicrobial action.

EtAce, DCM and Hex presented, in their majority, antimicrobial activity that is considered to be between moderate and low, and no tannins were found. On the other hand, Ace, with the proven presence of tannins, presented 
a better performance, with moderate antimicrobial activity for most (8/11) of the tested strains.

These results agree with those found in the literature for different Eugenia species, such as Eugenia umbeliflora (Machado et al., 2005), Eugenia pyriformis (Souza et al., 2014), Eugenia brejoensis (Azevedo et al., 2012) and Eugenia brasiliensis (Magina et al., 2012). It is also worth noting that the methanolic extract of Eugenia uniflora leaves has a high inhibition for both Gram positive and Gram negative bacteria $(10-156 \mu \mathrm{g} / \mathrm{mL}$ ) (Bouzada et al., 2009) and ethanolic extract with MIC (S. aureus, S epidermidis, B. subtilis, E. coli, and $P$. aerugionosa) (Fiúza et al., 2009). However, data on the antimicrobial potential of $E$. involucrata extracts were not verified in the literature; this is the first report on the antimicrobial potential of this species.

The antimicrobial profile of the vegetal extracts against the yeast $C$. albicans showed moderate to low action, except for DW with a MBC of $200 \mathrm{mg} / \mathrm{mL}$, which is considered very low. Similar results were found for the antifungal activity of the hydroalcoholic extract of E. uniflora compared to three species of Candida (MIC between 31.2 and $125 \mu \mathrm{g} / \mathrm{mL}$ ) (Holetz et al., 2002).

Due to the proven antimicrobial properties of the secondary metabolites in plants, it is suggested that the antimicrobial potential of $E$. involucrata plant extracts are related to its phytochemical profile. According to the literature, the flavonoids present in $\mathrm{MeOH}, \mathrm{EtOH}$, EtAce and DW are hydroxylated phenolic substances with proven antimicrobial activities. In turn, these act to form complexes with extracellular and soluble proteins, which bind to the bacterial cell wall to cause irreversible cell damage (Sher, 2009; Samy and Gopalakrishnakone, 2010).

The tannins present in $\mathrm{MeOH}, \mathrm{EtOH}$, Ace and DW, also belonging to the group of phenolic compounds, are characterized by their astringency properties, in addition to inhibiting Gram positive bacteria that cause food deterioration (B. subtilis), pathogens transmitted via contaminated food (S. aureus), as well as Gram negative bacteria (E. coli), and the proven inhibition of the growth of many fungi and yeasts (Samy and Gopalakrishnakone 2010; Gyawali and Ibrahim 2014). Its mode of action may be related to the formation of complexes with enzymes and microbial proteins, inactivating their functions, which may inhibit the transport of electrons through membranes, or even cause changes in the copper and iron ions related to the activities of some essential cell enzymes (Sher 2009; Samy and Gopalakrishnakone, 2010; Mendez et al., 2012; Gyawali and Ibrahim, 2014). In addition, the saponins

Table 2. Minimum Inhibitory Concentration (MIC), Minimum Bactericidal Concentration (MBC), Minimum Fungicidal Concentration (MFC) of aqueous and organic solvent extracts on leaves of E. involucrata against different pathogenic strains.

\begin{tabular}{|c|c|c|c|c|c|c|c|}
\hline \multirow{3}{*}{\begin{tabular}{|l} 
Microorganisms \\
Gram positives
\end{tabular}} & \multicolumn{7}{|c|}{ MIC/MBC (mg/mL) } \\
\hline & \multicolumn{7}{|c|}{ Extracting solvente } \\
\hline & МeOH & EtOH & EtAce & Ace & Hex & DCM & DW \\
\hline $\begin{array}{l}\text { S. aureus } \\
\text { (ATCC 25923) }\end{array}$ & $3.12 / 25$ & $3.12 / 6.25$ & $25 / 50$ & $12.5 / 25$ & $12.5 / 50$ & $12.5 / 100$ & $50 / 50$ \\
\hline $\begin{array}{l}\text { S. epidermidis } \\
\text { (ATCC 12228) }\end{array}$ & $12.5 / 12.5$ & $6.25 / 12.5$ & $12.5 / 25$ & $12.5 / 12.5$ & $100 / 100$ & $12.5 / 50$ & $50 / 100$ \\
\hline $\begin{array}{l}\text { E. faecalis } \\
\text { (ATCC 19433) }\end{array}$ & $6.25 / 12.5$ & $12.5 / 50$ & $100 / 100$ & $12.5 / 50$ & $25 / 50$ & $25 / 200$ & $50 / 50$ \\
\hline $\begin{array}{l}\text { B. subtilis } \\
\text { (CCCD B005) }\end{array}$ & $3.12 / 6.25$ & $6.25 / 12.5$ & $12.5 / 25$ & $12.5 / 12.5$ & $50 / 50$ & $6.25 / 12.5$ & $100 / 200$ \\
\hline \multicolumn{8}{|l|}{ Gram negatives } \\
\hline $\begin{array}{l}\text { S. Typhimurium } \\
\text { (ATCC 14028) }\end{array}$ & $25 / 25$ & $12.5 / 25$ & $25 / 100$ & $12.5 / 25$ & $50 / 100$ & $50 / 50$ & $50 /-$ \\
\hline $\begin{array}{l}\text { S. Enteritidis } \\
\text { (ATCC 13076) }\end{array}$ & $25 / 25$ & $12.5 / 25$ & $25 / 50$ & $12.5 / 25$ & $50 / 100$ & $50 / 100$ & $50 /-$ \\
\hline $\begin{array}{l}\text { E. coli } \\
\text { (ATCC 25922) }\end{array}$ & $12.5 / 25$ & $12.5 / 25$ & $12.5 / 25$ & $12.5 / 25$ & $25 / 50$ & $25 / 50$ & $50 /-$ \\
\hline $\begin{array}{l}\text { K. pneumoniae } \\
\text { (ATCC 13883) }\end{array}$ & $25 / 25$ & $25 / 50$ & $6.25 / 6.25$ & $6.25 / 12.5$ & $50 / 50$ & $12.5 / 50$ & $-1-$ \\
\hline $\begin{array}{l}\text { P. mirabilis } \\
\text { (ATCC 25933) }\end{array}$ & $6.25 / 12.5$ & $12.5 / 12.5$ & $25 / 50$ & $12.5 / 25$ & $50 / 100$ & $50 / 50$ & $100 /-$ \\
\hline $\begin{array}{l}\text { P. aeruginosa } \\
\text { (ATTC 27853) }\end{array}$ & $12.5 / 25$ & $12.5 / 12.5$ & $25 / 50$ & $25 / 50$ & $50 / 100$ & $12.5 / 100$ & $50 /-$ \\
\hline Yeast & \multicolumn{7}{|c|}{ MIC/MFC (mg/mL) } \\
\hline $\begin{array}{l}\text { C. albicans } \\
\text { (ATCC 10231) }\end{array}$ & $12.5 / 25$ & $12.5 / 50$ & $25 / 25$ & $50 / 50$ & $25 / 25$ & $25 / 50$ & $50 / 200$ \\
\hline
\end{tabular}

(-) No activity; Methanol (MeOH), ethanol (EtOH), ethyl acetate (EtAce), acetone (Ace), hexane (Hex), dichloromethane (DCM) and distilled water (DW). 
found in $\mathrm{MeOH}$, EtOH and DW have been reported to have antimicrobial potential, acting on the bacterial cell membrane and increasing its permeability (Simões et al., 2004; Gyawali and Ibrahim, 2014).

In general, all the extracts affected the growth or caused the death of the pathogenic strains, suggesting that the compounds present in these extracts, mainly the phenolic compounds, play an important antimicrobial role against the tested strains.

Some recent studies report properties of methanolic extracts as being and important antimicrobial and antioxidant; in the study of Liaqat et al. (2019), the methanolic extract of Allium sativum exhibited better antimicrobial performance against $E$. coli and $S$. aureus. In the study developed by Aliakbarlu and Tajik (2012) the methanolic extract of Borago officinalis flowers presented the most antioxidant potential, the E. involucrata extract reported here has the two outstanding characteristics.

\subsection{Antioxidant activity}

The antioxidant capacity of E. involucrata plant extracts were determined by a DPPH free radical sequestration assay (Table 3). This assay is a direct and reliable method for measuring the anti-radical capacity of plant extracts (Cabana et al., 2013).

The extracts that presented the highest sequestration of DPPH radicals were $\mathrm{MeOH}, \mathrm{EtOH}$ and Ace at the concentration of $1.0 \mathrm{mg} / \mathrm{mL}$, obtaining antioxidant percentages of $95.85,92.84$ and $91.13 \%$, respectively; their $\mathrm{IC}_{50}$ values were considered to be the same when compared to each other $(p<0.05)$. Among all the tested plant extracts, $\mathrm{MeOH}$ showed an $\mathrm{IC}_{50}$ value equal to the value found for the commercial antioxidant BHT ( $\mathrm{p}<0.05)$. On the other hand, EtAce, Hex, DCM and DW expressed significant differences in $\mathrm{IC}_{50}$ values when compared to each other and to BHT ( $p<0.05$; Table 4 ). Due to the questionable toxicity of the synthetic antioxidant BHT with respect to human health and consumer preferences for natural products, studies with antioxidants in Eugenia spp., mainly related to its phenolic content, are increasingly common (Durling et al., 2007; Fernández-Agulló et al., 2013; Queiroz et al., 2015).

The sequestration effect of the extracts was concentration dependent. In general, some extracts required higher concentrations to reach the maximum antioxidant potential., However, all extracts had an excellent percentage of DPPH sequestration (above 70\%) and the decline in antioxidant activity followed this descending order: $\mathrm{MeOH}>$ EtOH $>$ Ace $>$ EtAce $>$ DW $>$ DCM $>$ Hex .

Thus, we verified the important role of solvents in the determination of biological activities, such as antioxidant and antimicrobial activity, as well as their determining characteristics in the extraction of bioactive compounds. Extracts based on water, hydroalcoholic mixtures, ethanol, methanol and acetone were more effective for the extraction of antioxidant compounds due to the high polarity and good solubility of the solvents, mainly for the extraction of phenolic compounds (Durling et al., 2007; Fernández-Agulló et al., 2013; Onivogui et al., 2015; Takao et al., 2015; Kharchoufi et al., 2018).

In spite of the fact that there are no reports of the antioxidant activity of the extracts of E. involucrata leaves, studies with its fruit have shown excellent antioxidant potential, correlated with their phenolic content (Infante et al., 2016; Nicácio et al., 2017).

The antioxidant activity of the extracts is related to the compounds capable of preserving the biological systems from the harmful effects of free radicals. Thus, their action prevents the deterioration of food, cosmetics and pharmaceutical products, as well as the growth of

Table 3. Percentage of antioxidant activity of aqueous and organic solvent extracts from the leaves of E. involucrata by the DPPH method.

\begin{tabular}{|c|c|c|c|c|c|c|c|c|}
\hline \multirow{3}{*}{$\begin{array}{c}\text { Concentration } \\
(\mathrm{mg} / \mathrm{mL})\end{array}$} & \multirow{3}{*}{$\begin{array}{c}\text { Control } \\
\text { (BHT) }\end{array}$} & \multicolumn{7}{|c|}{ Plant extracts of $E$. involucrata } \\
\hline & & \multicolumn{7}{|c|}{ Extracting solvent } \\
\hline & & МeOH & EtOH & EtAce & Ace & Hex & DCM & DW \\
\hline 15 & - & - & - & - & - & $80.82 \pm 3.03$ & - & - \\
\hline 10 & - & - & - & - & - & $66.09 \pm 2.42$ & $77.05 \pm 0.80$ & - \\
\hline 7.5 & - & - & - & - & - & $49.07 \pm 2.42$ & $69.67 \pm 0.80$ & $87.05 \pm 0.10$ \\
\hline 5.0 & - & - & - & - & - & $44.06 \pm 3.23$ & $54.57 \pm 1.11$ & $83.83 \pm 0.40$ \\
\hline 2.5 & - & - & - & $91.13 \pm 0.14$ & - & $25.60 \pm 0.80$ & $34.61 \pm 1.01$ & $57.79 \pm 0.60$ \\
\hline 1.0 & - & $95.85 \pm 0.29$ & $92.84 \pm 0.62$ & $64.52 \pm 2.64$ & $91.13 \pm 1.03$ & - & $16.88 \pm 0.20$ & $29.68 \pm 0.10$ \\
\hline 0.75 & - & $92.98 \pm 0.36$ & $85.69 \pm 3.17$ & $54.5 \pm 0.89$ & $80.82 \pm 0.83$ & - & - & $24.46 \pm 0.40$ \\
\hline 0.50 & $94.92 \pm 0.91$ & $80.68 \pm 2.72$ & $74.64 \pm 3.27$ & $39.34 \pm 2.49$ & $69.52 \pm 0.97$ & - & - & - \\
\hline 0.25 & $85.12 \pm 1.61$ & $54.22 \pm 0.87$ & $48.49 \pm 3.05$ & $23.46 \pm 1.15$ & $42.48 \pm 3.08$ & - & - & - \\
\hline 0.10 & $57.65 \pm 1.82$ & $27.46 \pm 1.00$ & $24.32 \pm 2.34$ & - & $21.17 \pm 1.65$ & - & - & - \\
\hline 0.05 & $37.41 \pm 0.50$ & - & - & - & - & - & - & - \\
\hline 0.025 & $24.46 \pm 1.01$ & - & - & - & - & - & - & - \\
\hline
\end{tabular}

(-) Not tested; BHT (commercial synthetic antioxidant Butylhydroxytoluene), methanol (MeOH), ethanol (EtOH), ethyl acetate (EtAce), acetone (Ace), hexane (Hex), dichloromethane (DCM) and distilled water (DW); Percentage of DPPH radical sequestration was expressed as mean \pm standard deviation. 
Table 4. Value of $\mathrm{IC}_{50}$ of aqueous and organic solvent extracts from the leaves of $E$. involucrata by the DPPH method. by the DPPH method.

\begin{tabular}{cccc}
\hline Samples & $\mathbf{I C}_{\mathbf{5 0}}(\mathbf{m g} / \mathbf{m L})$ & Equation & $\mathbf{R}^{\mathbf{2}}$ \\
\hline BHT & $0.11 \pm 0.003 \mathrm{a}$ & $\mathrm{y}=0.1396 \mathrm{x}+34.088$ & 0.82 \\
$\mathrm{MeOH}$ & $0.24 \pm 0.014 \mathrm{ab}$ & $\mathrm{y}=0.0744 \mathrm{x}+31.536$ & 0.87 \\
EtOH & $0.31 \pm 0.036 \mathrm{~b}$ & $\mathrm{y}=0.0741 \mathrm{x}+26.697$ & 0.90 \\
EtAce & $0.82 \pm 0.050 \mathrm{c}$ & $\mathrm{y}=0.0275 \mathrm{x}+27.136$ & 0.89 \\
Ace & $0.37 \pm 0.018 \mathrm{~b}$ & $\mathrm{y}=0.0761 \mathrm{x}+21.442$ & 0.93 \\
Hex & $7.28 \pm 0.107 \mathrm{~d}$ & $\mathrm{y}=0.0043 \mathrm{x}+18.501$ & 0.96 \\
DCM & $5.09 \pm 0.018 \mathrm{e}$ & $\mathrm{y}=0.0067 \mathrm{x}+15.892$ & 0.95 \\
DW & $2.66 \pm 0.002 \mathrm{f}$ & $\mathrm{y}=0.0096 \mathrm{x}+24.327$ & 0.89 \\
\hline
\end{tabular}

BHT (commercial synthetic antioxidant Butylhydroxytoluene), methanol (MeOH), ethanol (EtOH), ethyl acetate (EtAce), acetone (Ace), hexane

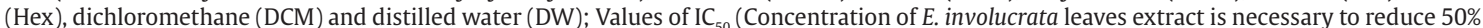
of the DPPH radical) expressed as mean \pm standard deviation; Different letters in the same column express significant differences ( $\mathrm{p}<0.05$ ); Equation (Allows to estimate expected value of variable $\mathrm{y}$, given the values of variable $\mathrm{x}$ ); $\mathrm{R}^{2}$ (Coefficient of determination of a linear statistical model that explains the percentage of relation of observed values).

undesirable microorganisms. In addition, they have a fundamental role in the cell damage and aging processes (Bozin et al., 2007; Fernández-Agulló et al., 2013). Given this, $\mathrm{MeOH}, \mathrm{EtOH}$ and Ace, together with DW, due to their low toxicity, are excellent candidates for industry use. It is suggested that their antioxidant potential is related to their phenolic content (flavonoids and tannins). These phenolic compounds can act by sequestering free radicals, thereby reducing the redox potential of the medium by chelating pro-oxidant metal ions and inhibiting some enzymes, which may also restrict the growth of contaminating microorganisms (Oliveira et al., 2009; Gyawali and Ibrahim, 2014).

\section{Conclusion}

This study aimed to provide unpublished information regarding the biological and phytochemical profile of the different extracts of E. involucrata leaves. According to phytochemical prospecting, plant extracts revealed the presence of saponins, free steroids, flavonoids (flavones, flavanols and flavanones) and tannins. The relationship between these classes of metabolites and their antimicrobial and antioxidant activities was inferred. The results showed excellent antimicrobial activity, which varied according to the extracting solvent and the tested microorganism. For antioxidant activity, the percentages of the sequestration of DPPH radicals were optimal, above $70 \%$. $\mathrm{MeOH}$ and $\mathrm{EtOH}$ presented the best results for the tested biological activities, demonstrating the influence of phenolic compounds. According to these promising results, information on the pool of phytochemicals and biological activities of E. involucrata is a valuable contribution to future bioassays and their possible use in different industry sectors.

\section{Acknowledgements}

The first author thanks the Coordination of Improvement of Higher Education Personnel - CAPES (government body linked to the Brazilian Ministry of Education charged with promoting high standards of postgraduate studies in Brazil) for the grant awarded for the study; and to the Herbarium of the State University of the West of Paraná (UNOP) for the botanical identification.

\section{References}

ALIAKBARLU, J. and TAJIK, H., 2012. Antioxidant and antibacterial activities of various extracts of Borago officinalis flowers. Journal of Food Processing and Preservation, vol. 36, no. 6, pp. 539-544. http://dx.doi.org/10.1111/j.1745-4549.2011.00622.x.

ANDRADE, D., GIL, C., BREITENFELD, L., DOMINGUES, F. and DUARTE, A.P., 2009. Bioactive extracts from Cistus ladanifer and Arbutus unedo L. Industrial Crops and Products, vol. 30, no. 1, pp. 165-167. http://dx.doi.org/10.1016/j.indcrop.2009.01.009.

AZEVEDO, P.R., SILVA, L.C.N., SILVA, A., MACEDO, J.M., ARAÚJO, J.M. and SILVA, M.V., 2012. Antimicrobial activity and phytochemical screening of branches, fruits and leaves of Eugenia brejoensis. Scientia Plena, vol. 8, pp. 1-4.

BOUZADA, M.L.M., FABRI, R.L., NOGUEIRA, M., KONNO, T.U.P., DUARTE, G.G. and SCIO, E., 2009. Antibacterial, cytotoxic and phytochemical screening of some traditional medicinal plants in Brazil. Pharmaceutical Biology, vol. 47, no. 1, pp. 44-52. http:// dx.doi.org/10.1080/13880200802411771.

BOZIN, B., MIMICA-DUKIC, N., SAMOJLIK, I. and JOVIN, E., 2007. Antimicrobial and Antioxidant properties of Rosemary and Sage (Rosmarinus officinalis L. and Salvia officinalis L., Lamiaceae) essential oils. Journal of Agricultural and Food Chemistry, vol. 55, no. 19, pp. 7879-7885. http://dx.doi.org/10.1021/jf0715323. PMid:17708648.

CABANA, R., SILVA, L.R., VALENTÃO, P., VITURRO, C.I. and ANDRADE, P.B., 2013. Effect of different extraction methodologies on the recovery of bioactive metabolites from Satureja parvifolia (Phil.) Epling (Lamiaceae). Industrial Crops and Products, vol. 48, pp. 49-56. http://dx.doi.org/10.1016/j.indcrop.2013.04.003.

CIARLINI, J.J.S., MARANGONI, A. and BOLZAN, A., 2017. Selectivity of supercritical $\mathrm{CO} 2$ extraction and atmospheric pressure techniques for the major volatile compounds of Eugenia involucrata leaves from Southern Brazil. Food and Bioproducts Processing, vol. 106, pp. 29-34. http://dx.doi.org/10.1016/j. fbp.2017.08.008.

DURLING, N.E., CATCHPOLE, O.J., GREY, J.B., WEBBY, R.F., MITCHELL, K.A., FOO, L.Y. and PERRY, N.B., 2007. Extraction of phenolic and 
essential oil from dried sage (Salvia officinalis) using ethanolwater mixtures. Food Chemistry, vol. 101, no. 4, pp. 1417-1424. http://dx.doi.org/10.1016/j.foodchem.2006.03.050.

FERNÁNDEZ-AGULLÓ, A., PEREIRA, E., FREIRE, M.S., VALENTÃO, P., ANDRADE, P.B., GONZÁLEZ-ÁLVAREZ, J. and PEREIRA, J.A., 2013. Influence of solvent on the antioxidant and antimicrobial properties of walnut (Juglans regia L.) green husk extracts. Industrial Crops and Products, vol. 42, pp. 126-132. http://dx.doi. org/10.1016/j.indcrop.2012.05.021.

FIÚZA, T.S., SABÓIA-MORAIS, S.M.T., PAULA, J.R., TRENSVENZOL, L.M.F. and PIMENTA, F.C., 2009. Evaluation of antimicrobial activity of the crude ethanol extract of Eugenia uniflora L. leaves. Journal of Basic and Applied Pharmaceutical Sciences, vol. 29, no. 3, pp. 245-250.

GYAWALI, R. and IBRAHIM, S.A., 2014. Natural products as antimicrobial agents. Food Control, vol. 46, pp. 412-429. http:// dx.doi.org/10.1016/j.foodcont.2014.05.047.

HOLETZ, F.B., PESSINI, G.L., SANCHES, N.R., CORTEZ, D.A.G., NAKAMURA, C.V. and DIAS-FILHO, B.P., 2002. Screening of some plants used in the Brazilian Folk Medicine for the treatment of infectious diseases. Memorias do Instituto Oswaldo Cruz, vol. 97, no. 7, pp. 1027-1031. http://dx.doi.org/10.1590/S007402762002000700017. PMid:12471432.

HÜLLER, A. and SCHOCK, A.A., 2011. Avaliação do potencial alelopático de três espécies de Eugenia L. (Myrtaceae) sobre o processo germinativo Lactuca sativa L. Revista de Ciências Ambientais, vol. 5, pp. 25-37.

INFANTE, J., ROSALEN, P.L., LAZARINI, J.G., FRANCHIN, M. and ALENCAR, S.V., 2016. Antioxidant and anti-inflammatory activities of unexplored brazilian native fruits. PLoS One, vol. 11, no. 4, pp. e0152974. http://dx.doi.org/10.1371/journal. pone.0152974. PMid:27050817.

KHARCHOUFI, S., LICCIARDELLO, F., SIRACUSA, L., MURATORE, G., HAMDI, M. and RESTUCCIA, C., 2018. Antimicrobial and antioxidant features of 'Gabsi' pomegranate peel extracts. Industrial Crops and Products, vol. 111, pp. 345-352. http:// dx.doi.org/10.1016/j.indcrop.2017.10.037.

LAZZAROTTO-FIGUEIRÓ, J., CAPELEZZO, A.P., SCHINDLER, M.S.Z., FOSSÁ, J.F.C., ALBENY-SIMÕES, D., ZANATTA, L., OLIVEIRA, J.V. and DAL MAGRO, J., 2021. Antioxidant activity, antibacterial and inhibitory effect of intestinal disaccharidases of extracts obtained from Eugenia uniflora L. Seeds. Brazilian Journal of Biology = Revista Brasileira de Biologia, vol. 81, no. 2, pp. 291-300. http://dx.doi.org/10.1590/1519-6984.224852. PMid:32696852.

LIAQAT, A., ZAHOOR, T., ATIF RANDHAWA, M. and SHAHID, M., 2019. Characterization and antimicrobial potential of bioactive components of sonicated extract from garlic (Allium sativum) against foodborne pathogens. Journal of Food Processing and Preservation, vol. 43, no. 5, pp. 1-8. http://dx.doi.org/10.1111/ jfpp.13936.

LIN, Y., LOU, K., WU, G., WU, X., ZHOU, X., FENG, Y., ZHANG, H. and YU, P., 2020. Bioactive metabolites in of Ginkgo biloba leaves: variations by seasonal, meteorological and soil. Brazilian Journal of Biology = Revista Brasileira de Biologia, vol. 80, no. 4, pp. 790-797. http://dx.doi.org/10.1590/1519-6984.220519. PMid:31800764.

LORENZI, H., 2009. Brazilian trees: identification and cultivation of native tree plants in Brazil. Rio de Janeiro: Instituto Plantarum, vol. 3.

MACHADO, K.E., CECHINEL FILHO, V., TESSAROLO, M.L., MALMANN, R., MEYRE-SILVA, C. and CRUZ, A.B., 2005. Potent antibacterial activity of Eugenia umbelliflora. Pharmaceutical Biology, vol. 43, no. 7, pp. 636-639. http://dx.doi.org/10.1080/13880200500303817.
MAGINA, M.D.A., DALMARCO, E.M., DALMARCO, J.B., CELLA, G., PIZOLUTTI, M.G. and BRIGHENTE, I.M.C., 2012. Bioactive triterpenes and phenolics of leaves of Eugenia brasiliensis. Quimica Nova, vol. 35, no.6, pp. 2-3. http://dx.doi.org/10.1590/ S0100-40422012000600022.

MARIN, R., APEL, M.A., LIMBERGER, R.P., RASEIRA, M.C., PEREIRA, J.F.M., ZUANAZZI, J.S. and HENRIQUES, A.T., 2008. Volatile Components and Antioxidant Activity from some Myrtaceous Fruits cultivated in Southern Brazil. Latin American Journal of Pharmacy, vol. 27, pp. 172-177.

MATOS, F.J.A., 1997. Introdução à fitoquímica experimental. Fortaleza: Fortaleza Edições UFC, Vol. 2.

MENDEZ, M., RODRIGUES, R., RUIZ, J., MORALES-ADAME, D., CASTILLO, F., HERNÁNDEZ-CÁSTILLO, F.D. and AGUILLAR, C.N., 2012. Antibacterial activity of plant extracts obtained with alternative organics solvents against food-borne pathogen bacteria. Industrial Crops and Products, vol. 37, no. 1, pp. 445450. http://dx.doi.org/10.1016/j.indcrop.2011.07.017.

MORESCO, H.H., COLLA, G., CAVALCANTE, I.D., QUEIROZ, G.S., PIZZOLATTI, M.G. and BRIGUENTE, I.M.C., 2016. Chemical constituents of Eugenia catharinae and their antioxidant activity. Natural Product Research, vol. 6419, no. 22, pp. 2624-2628. http:// dx.doi.org/10.1080/14786419.2015.1131981. PMid:26758384.

NICÁCIO, A.E., ROTTA, E.M., BOEING, J.S., BARIZÃO, E.O., KIMURA, E., VISENTAINER, J.V. and MALDANER, L., 2017. Antioxidant activity and determination of phenolic compounds from Eugenia involucrata DC. Fruits by UHPLC-MS/MS. Food Analytical Methods, vol.10, no. 8, pp. 2718-2728. http://dx.doi.org/10.1007/ s12161-017-0840-3.

OLIVEIRA, A.P., VALENTÃO, P., PEREIRA, J.A., SILVA, B.M., TAVARES, F. and ANDRADE, P.B., 2009. Ficus carica L.: metabolic and biological screening. Food and Chemical Toxicology, vol. 47, no. 11, pp. 2841-2846. http://dx.doi.org/10.1016/j.fct.2009.09.004. PMid:19747518.

OLIVEIRA, V.B., YAMADA, L.T., FAGG, C.W. and BRANDÃO, M.G.L., 2012. Native foods from Brazilian biodiversity as a source of bioactive compounds. Food Research International, vol. 48, no. 1, pp. 170-179. http://dx.doi.org/10.1016/j.foodres.2012.03.011.

ONIVOGUI, G., LETSIDIDI, R., DIABY, M., WANG, L. and SONG, Y., 2015. Influence of extraction solvents on antioxidant and antimicrobial activities of the pulp and seed of Anisophyllea laurina R. Br. ex Sabine fruits. Asian Pacific Journal of Tropical Biomedicine, vol. 6, pp. 1-6. http://dx.doi.org/10.1016/j.apjtb.2015.09.023.

PANDINI, J.A., PINTO, F.G.S., SCUR, M.C., ALVES, L.F.A. and MARTINS, C.C., 2015. Antimicrobial, insecticidal and antioxidant activity of essential oil and extracts of Guarea kunthiana A. Juss. Journal of Medicinal Plants Research, vol. 9, no. 3, pp. 48-55. http:// dx.doi.org/10.5897/JMPR2014.5551.

PIMENTEL, F.A., CARDOSO, G., GUIMARÃES, L.G.L., QUEIROZ, F., BARBOSA, L.C.A., MORAIS, A.R., NELSON, D.L., ANDRADE, M.A., ZACARONI, L.M. and PIMENTEL, S.M.N.P., 2013. Extracts from the leaves of Piper piscatorum (Trel. Yunc.) obtained by supercritical extraction of with $\mathrm{CO} 2$, employing ethanol and methanol as co-solvents. Industrial Crops and Products, vol. 43, pp. 490-495. http://dx.doi.org/10.1016/j.indcrop.2012.07.067.

PINELO, M., RUBILAR, M., SINEIRO, J. and NÚÑEZ, J., 2004. Extraction of antioxidant phenolics from almond hulls (Prunus amygdalus) and pine sawdust (Pinus pinaster). Food Chemistry, vol. 85, no. 2, pp. 267-273. http://dx.doi.org/10.1016/j.foodchem.2003.06.020.

POIROT, R., PRAT, L., GOURDON, G., DIARD, C. and AUTRET, J.M., 2006. Fast batch to continuous solid-liquid extraction from plants in continuous industrial extractor. Chemical Engineering 
ETechnology, vol. 29, no. 1, pp. 46-51. http://dx.doi.org/10.1002/ ceat.200600304.

QUEIROZ, M.G., SUZUKI, M.C.M. and MOTTA, A.P.R., 2015. Aspectos populares e científicos do uso de espécies de Eugenia como fitoterápico. Etnofarmacologia, vol. 9, pp. 87-100. http://dx.doi. org/10.5935/2446-4775.20150008.

RUFINO, M.S.M., ALVES, R.E.B., MORAIS, E.S.M., SAMPAIO, S.M.S. GOES, C. and PÉREZ-JIMÉNEZ, J. 2007 [viewed 19 November 2020]. Metodologia científica: determinação da atividade antioxidante total em frutas pela captura do radical livre DPPH [online]. Fortaleza: Embrapa Agroindústria Tropical. Comunicado técnico, no. 127. Available from: https://ainfo.cnptia.embrapa. br/digital/bitstream/CNPAT/10224/1/Cot_127.pdf

SAMY, R.P. and GOPALAKRISHNAKONE, P., 2010. Therapeutic potential of plants as anti-microbials for drug discovery. Evidence-Based Complementary and Alternative Medicine, vol. 7, no. 3, pp. 283-294. http://dx.doi.org/10.1093/ecam/nen036. PMid: 18955349.

SAUSEN, T.L., LOWE, T.R., FIGUEIREDO, L.S. and BUZATTO, C.R., 2009. Avaliação da atividade alelopática do extrato aquoso de folhas de Eugenia involucrata DC. e Acca sellowiana (O. Berg) Burret. Polibotánica, vol. 27, pp. 145-158.

SHARMA, B., BALOMAJUMDER, C. and ROY, P., 2008. Hypoglycemic and hypolipidemic effects of flavonoid rich extract from Eugenia jambolana seeds on streptozotocin induced diabetic rats. Food and Chemical Toxicology, vol. 46, no. 7, pp. 2376-2383. http:// dx.doi.org/10.1016/j.fct.2008.03.020. PMid:18474411.

SHER, A., 2009. Antimicrobial activity of natural products from medicinal plants. Gomal Journal of Medical Sciences, vol. 7, no. 1, pp. 72-78.

SIMÕES, C.M.O., SCHENKEL, E.P., GOSMAN, G., MELLO, J.C.P., MENTZ, L.A. and PETROVICK, P.R. (2004) Farmacognosia: da planta ao medicamento. Porto Alegre: UFSC.

SIMONETTI, E., ETHUR, M.E., CASTRO, L.C., KAUFFMANN, C., GIACOMIN, A.C., LEDUR, A., AROSSI, K., PACHECO, L.A., GOETTERT, M.I., FALEIRO, D. and FREITAS, E.M., 2016. Avaliação da atividade antimicrobiana de extratos de Eugenia anomala e Psidium salutare (Myrtaceae) frente à Escherichia coli e Listeria monocytogenes. Revista Brasileira de Plantas Medicinais, vol. 18, no. 1, pp. 9-18. http://dx.doi.org/10.1590/1983-084X/15_005.

SOBRAL, M., PROENÇA, C., SOUZA, M., MAZINE, F. and LUCAS, E., 2015 [viewed 19 November 2020]. Myrtaceae. Lista de Espécies da Flora do Brasil [online]. Rio de Janeiro: Jardim Botânico do Rio de Janeiro. Available from: http://reflora.jbrj.gov.br/jabot/ FichaPublicaTaxonUC/FichaPublicaTaxonUC.do?id=FB10338
SOOD, R., SWARUP, D., BHATIA, S., KULKARNI, D.D., DEY, S., SAINI, M. and DUBEY, S.C., 2012. Antiviral activity of crude extracts of Eugenia jambolana Lam. against highly pathogenic avian influenza (H5N1) virus. Indian Journal of Experimental Biology, vol. 50, no. 3, pp. 179-186. PMid:22439432.

SOUZA, A.M., ARMSTRONG, L., MERINO, F.J.Z., COGO, L.L., MONTEIRO, C.L.B., DUARTE, M.R., MIGUEL, O.G. and MIGUEL, M.D., 2014. In vitro effects of Eugenia pyriformis Cambess., Myrtaceae: Antimicrobial activity and synergistic interactions with Vancomycin and Fluconazole. African Journal of Pharmacy and Pharmacology, vol. 8, no. 35, pp. 862-867. http://dx.doi. org/10.5897/AJPP2014.4100.

TAKAO, L.K., IMATOMI, M. and GUALTIERI, S.C.J., 2015. Antioxidant activity and phenolic content of leaf infusions of Myrtaceae species from Cerrado (Brazilian Savanna). Brazilian Journal of Biology = Revista Brasileira de Biologia, vol. 75, no. 4, pp. 948-952. http://dx.doi.org/10.1590/1519-6984.03314. PMid:26675912.

TEIXEIRA, R. and SILVA, L.R., 2013. Bioactive compounds and in vitro biological activity of Euphrasia rostkoviana Hayne extracts. Industrial Crops and Products, vol. 50, pp. 680-689. http://dx.doi. org/10.1016/j.indcrop.2013.08.035.

TIWARI, P., KUMAR, B., KAUR, M., KAUR, G. and KAUR, H., 2011. Phytochemical screening and extraction: a review. Internationale Pharmaceutica Sciencia, vol. 1, no. 1, pp. 98-106.

WEBER, L.D., PINTO, F.G.S., SCUR, M.C., SOUZA, J.G.L., COSTA, W.F. and LEITE, C.W., 2014. Chemical composition and antimicrobial and antioxidant activity of essential oil and various plant extracts from Prunus myrtifolia (L.) Urb. African Journal of Agricultural Research, vol. 9, no. 9, pp. 846-853. http://dx.doi.org/10.5897/ AJAR2013.8260.

WONGKITTIPONG, R., PRAT, L., DAMRONGLERD, S. and GOURDON, C., 2004. Solid-liquid extraction of andrographolide from plantsexperimental study, kinetic reaction and model. Separation and Purification Technology, vol. 40, no. 2, pp. 147-154. http:// dx.doi.org/10.1016/j.seppur.2004.02.002.

WORLD HEALTH ORGANIZATION - WHO, 1998. Guidelines for the appropriate use of herbal medicines. 23rd ed. Geneva: WHO. WHO Country Office in Philippines.

ZIANI, B.E.C., CALHELHA, R.C., BARREIRA, J.C.M., BARROS, L., HAZZIT, M. and FERREIRA, I.C.F.R., 2015. Bioactive properties of medicinal plants from the Algerian flora: selecting the species with the highest potential in view of application purposes. Industrial Crops and Products, vol. 77, pp. 582-589. http://dx.doi.org/10.1016/j. indcrop.2015.09.034. 